\title{
Pattern of Public Expenditure in Nigeria: Excessive or Responsive
}

\author{
ADEBANWA Ayowole Abayomi, RUFAI Aliyu Akorede, MARTINS Bolaji Adeolu
}

\begin{abstract}
This study empirically investigates the pattern of Federal government's expenditure in Nigeria, as to resolving the arguments in the literature, as to whether government spending pattern is excessive or recessive. The study employed the Wagner's theoretical framework and the model is estimated with time series data from 1980 to 2018 , using the aggregate government expenditure on General Administration; Social and community services; Economic services and Transfers. Ordinary Least Square (OLS) was used to estimate the numerical values of the parameters of the model. Unit root test was conducted to establish the stationarity of the variables while post -estimation tests were conducted to test for normality, heteroscedasticity and auto correlation.
\end{abstract}

From the descriptive statistics, the kurtosis of 2.26 (which is less than 3) showed that government spending in Nigeria, tends to be excessive as aggregate spending on transfers is highly skewed while the all the explanatory variables have joint significant influence of the rise in government expenditure, as Wagner posited.

Based on the findings, the study recommends the need for government to reduce aggregate expenditure on Transfers as a result, blocking several leakages in the Nigerian economy, which are capable of truncating the pursuit of macro-economic goals in Nigeria.

Index Terms - Public expenditure, excessive, recessive, Wagners' theory.

\section{INTRODUCTION}

The growth of government expenditure poses a problem for several government policies, most especially budget control and debt management, particularly if government revenue is not rising more than proportionately (Taiwo, 1989). The danger posed by rising public spending to government budget and therefore debt management engenders the need to examine the focus and pattern of public expenditure in Nigeria is the general objective of this term paper.

Developing countries like Nigeria often fail to coordinate their efforts/actions when considering their fiscal spending pattern as this is essential for rapid and sustained economic growth and development. This research problem is contextualized in the pattern of government spending: Is it responsive or excessive?This paper hopes to examine the pattern of government spending as to whether it is responsive to the demands of her citizens or excessive in terms of maximizing selfish interests of political office holders, who

ADEBANWA Ayowole Abayomi, Department of Social Sciences, Yaba College of Technology, Yaba, Lagos, Nigeria.

RUFAI Aliyu Akorede, Department of Economics, Babcock University, Ilishan, Ogun State, Nigeria

MARTINS Bolaji Adeolu, Department of Economics, Babcock University, Ilishan, Ogun State, Nigeria controls the machinery of government. Specifically, this paper intends to measure how federal government expenditure spur responsiveness or otherwise on the growth of the Nigerian economy from 1980 - 2018.

Several plausible explanations have been offered to explain the reasons for increase in government spending in developed and developing economies, thereby resulting in the argument in the literature: whether the public expenditure pattern of the government is excessive or recessive? Berry \& Lowery (1987) pioneered this debate as they gave explanations for these two terms. They explained that the total size of government is dictated by the focus and pattern of government fiscal spending. This focus and pattern are characterized as either "responsive" or "excessive" government spending. The term 'Responsiveness' view government spending as significant to economic growth, while the term 'Excessiveness' view government spending as not significant to economic growth. However, they did not ascertain the causal factors that account for 'excessiveness' or 'responsiveness' of government spending in developing economies like Nigeria.

Government fiscal spending in Nigeria has continued to rise due to the rise in the cost of governance and the increased demand for public (utilities) goods like roads, communication, power, education and health. Available statistics showed that government expenditure (capital and recurrent) and its components have continued to rise in the last three decades. For instance, government total recurrent expenditure increased from N4, 805.20 million in 1980 to $\mathrm{N} 36,219.60$ million in 1990 and further to N1, 589,270.00 in 2007. On the other hand government capital expenditure rose from N10, 163.40 million in 1980 to $\mathrm{N} 24,048.60$ million in 1990. Capital expenditure stood at N239, 450.90 million and N759, 323.00 million in 2000 and 2007 respectively. The various components of capital expenditure have risen between 1980 and 2017. However, the rising government expenditure may have not translated to meaningful growth and development, as Nigeria ranks among the poorest countries in the world (Okoro, 2013).

In addition, many Nigerians have continued to wallow in abject poverty, while more than fifty percent live on less than US\$1per day. Moreover, macroeconomic indicators like balance of payments, import obligations, inflation rate, exchange rate, and unemployment rate reveal that Nigeria has not fared well in the last three decades. It is disturbing to note that government expenditure seems to have not replicated same level of economic growth in Nigeria, for instance between 1980 and 1990, while the GDP growth rate was decreasing $(57.15 \%$ down to $2.87 \%)$, government 
expenditure growth rate was increasing (23.2\% to $41.24 \%)$. Thus, there is an inverse relationship between the two periods. However, it is found that the growth rate of government expenditure in 2000 and 2010 was $15.53 \%$ and $2.15 \%$ respectively, while GDP growth rate witnessed $8.79 \%$ and $1.54 \%$ in the same period respectively. Thus, government expenditure growth rate has been greater than GDP growth in the same period (Okoro, 2013). Furthermore, Nigeria's Government Expenditure is forecasted to be 18,392.991 bn in December 2019 as reported by International Monetary Fund World Economic Outlook. It records an increase from the last reported number of 16,828.759 NGN bn in December 2018. Looking ahead, Nigeria's Government Expenditure is projected to stand at 30,277.552 NGN bn in December 2024. These figures are in fact worrisome when compared the Nigeria's GDP.

Okafor \&Eiya (2011) identified four determinants of growth in public expenditure: Inflation, Public debt, tax revenue and population. Furthermore, Ukwueze (2015) \&Umar (2015) identified: Population growth, increase in national income, defence expenses, increase in welfare activities, expansion of administrative machinery, government subsidies, development projects, industrialization and investment in education are some of the reasons for increase in the public expenditure. While these factors were responsible for the changing size of government in the developed countries, there had been no concensus as to whether the pattern of the Nigerian government expenditure is excessive or responsive.

While some researchers argue that in developed and emerging economies, growth in public expenditure is "responsive" as there is a long run relationship between public expenditure and economic growth (Ezirim\&Ofurum, 2003; Muritala\& Taiwo, 2011; Gbenga, Babatunde \& Esther (2015). Other researchers argued that there is "excessiveness" in the fiscal budget of governance. Adeolu\&Osabuohien, (2007); Ighodaro\&Oriakhi (2010); Amassoma, Nwosa, \&Ajisafe (2011); Modebe, Okafor, Onwumere\&Ibe, I. G. (2012); Ganiyu, Olawale, Ajibade\&Abisola, (2016); Theophilus \&Perpectua (2016).

Relevant questions in this research work are: Does government spending spur economic growth? Does the nexus between government spending and economic growth follow the Wagner's law? Does increase in poverty level reflects the 'excessiveness' of government spending in Nigeria? Does increase in the sectoral allocations of public expenditure explains the 'responsiveness' of the government? These questions shall be answered in the course of the findings.

Thus, this paper hopes to validate these arguments as to whether the Federal government of Nigeria's fiscal spending pattern is 'excessive' or 'responsive'. Hence, the paper shall be divided into the following sections:

\section{BACKGROUND TO THE STUDY}

Government spending is generally referred to as spending made by the government of a country on collective needs and wants such as pension, provision, infrastructure, etc to promote societal welfare. In the 17th and the 18th centuries, public expenditure was considered as a wastage of money.
Thinkers said government should stay with their traditional functions of spending on defence and maintaining law and order.

History has it that until the 19th century, public expenditure was limited as laissez faire philosophies of capitalism, which is believed that money left in private hands could bring better returns. In the 20th century, John Maynard Keynes argued the role of public expenditure in determining levels of income and distribution in the economy. Since then, government expenditures has shown an increasing trend, both in developed and developing countries.

Government spending refers to public expenditure on goods and services and is a major component of the GDP. Government spending policies like setting up budget targets, adjusting taxation, increasing public expenditure and public works are very effective tools in influencing economic growth.

Gaurav (2011) sees public expenditure as the expenditure incurred by the public authorities like the central, state and local government of a country to satisfy the collective social wants of the people.

Public expenditure denotes the dispensation of the state on non-market criteria of economic resources that has acquired from firms and households. However, the detail is highly complex because the modern state is such a difficult concept to analyze. Consequently, care is always required in the interpretation of public expenditure figures, particularly when these become the subject of heated political debate (Onyinlola, 2013).

Comparatively, in developing countries like Nigeria, the public sector is usually predominant. The reason appears to lie in what the government perceives as its social responsibility or share of commitment in the growth and development process. Its largeness has also been stimulated by the urge to adopt shock adjustment to economic growth for quicker realization of national aspirations. Considering the ease with the public sector adjusted government expenditures to mop up the inflow of wealth and foreign exchange during the period of the oil boom, one benefit of a large public sector becomes evident, namely, the preoccupation with distribution of the fruits of economic growth to a progressively large percentage of the growing population (Adeyemo, 1989).

According to Olugbenga and Owoye (2007) and Ezirim and Ofurum (2003), public expenditure is usually categorized into recurrent and capital expenditure. These are further broken down into their compositions. For instance, recurrent expenditure is composed of administration/defence, general administration, internal security, economic services (agriculture, construction, transportation and communication and others) social and community services such as education, health and others.

Some public expenditure may be in the form of education, various social services and so on in which case it will lead to an increase in consumption rather than savings. On the other hand, public expenditure helps the people in attaining higher efficiency and productivity, their capacity to work and save increases. But above all, we must recognize the lead which public expenditure, if used in a judicious way and with a purpose can give to the economy. It has the capacity to open 
up vast opportunities and it can create an awakening and desire in the mind of the people to improve their lot (Ojong, Nkamare\&Ogar, 2016).

In Nigeria, government expenditure has nominally been on the increase due to oil revenue which is now the mainstay of the Nigerian economy. This over dependence on extractive industry and commodity export (traditional capital) characterize not only the Nigerian economy but also other sub-Saharan Africa. This reinforces the need to review the public expenditure structure in these countries since the success of government fiscal policy implementation depends upon efficient public expenditure management and also the effectiveness of Government's fiscal measures/operations is seen against the back drop of the extent to which they help in achieving the macro-economic objectives (Akonji, Olateju\& Abba, 2013).

Thus, Government expenditure in Nigeria has been increasing very significantly since 1960 . This increase has been due to a number of social, political and economic factors which greatly increased the level of government activity. During the 1950's the total government has been increasing as the need for government to respond to the demands of her citizenry increased as a resulting of greater awareness of the role of government in participating actively and to supervise the economy.

However, the consistent growth of government expenditure has been at a reducing rate relative to GDP growth that has been increasing at an increasing rate. This development accounts for fluctuations in the government expenditure-GDP ratio in Nigeria.

On the average, the ratio of expenditure to GDP from 1970 to 1979 stood at $21 \%$ which it still maintained in the period 1980 to 1989 but dropped

to $19.6 \%$ in 1990 to 1999 and further reduced to $13.1 \%$ between the year 2000 to 2010 (CBN Statistical bulletin, 2011).

Further to 2018, there had been an upward increase in both the Recurrent and Capital Expenditure of the Nigerian Government especially since the attainment of democracy in 1999 till the current period under review, as seen in Table 1(check APPENDIX I).

Similarly, by way of extrapolating the components of the Nigerian Public expenditure as contained in the CBN Statistical Bulletin, increasing trends were observed of the pattern of both capital and recurrent expenditure onAdministration; Social and Community services; Economic services, and transfers as shown in the Table 1 above.

Maku (2009) observed that the mechanism through which government spending on public infrastructure is expected to affect the pace of economic growth depends largely on the precise form and size of total public expenditure allocated to economic and social development projects in the economy. He however believed that public expenditure on social and economic infrastructure in education, health, transportation, communication, waste disposal, water, electricity, and sanitation etc., can contribute to the performance of the economy in the following ways;

- Promotion of infant industries in the country

- Reduction in the unemployment rate

- Stabilization of the general prices in the country

- Reduction in the poverty rate and increase in the standard of living of the people

- Promotion of higher productivity through efficient utilization of factor inputs

To corroborate the above scenario, Jibir\&Aluthge (2019) asserted that the Nigerian government activities vis-à-vis public expenditure has grown rapidly both in absolute, relative and as a share of GDP over the years. These growths in government expenditure have been due to certain factors which are believed to have significant effect on the fiscal operation of the country. These perceived implications of government expenditure expansion on the economy necessitate the need to understand factors that are responsible for the growth in government expenditure size.

\section{LITERATURE REVIEW}

\section{Theoretical Review:}

\section{Wagner's Theory}

Adolph Wagner argued that growth in government expenditure is a function of increased industrialization and economic development. Following Wagner's Law, as the national income rises, the public expenditure also rises to meet the demands of the people. As the economy grows and income rises, the demand for goods, including public goods will rise, which as a consequence pushes the public expenditure up. With rise in per capita income, public provision of consumer goods also rises.

Changes in the general population might affect some services, such as defence, police protection, or fire protection, whereas, in other cases, it is a specific section of the population that is of importance for the provision of the service, for example, the school-age population in the case of education. Ukwueze, (2015).

\section{Peacock \& Wiseman Theory}

Peacock and Wiseman (1967) suggested that the growth in public expenditure does not occur in the same way that Wagner theorized. Peacock and Wiseman choose the political propositions instead of the organic state where it is deemed that government like to spend money, people do not like increasing taxation and the population voting for ever-increasing social services.

\section{Classical approach of public expenditure}

In his Welfare of Nations, Adam Smith (1776) advocated much on the "laissez-faire" economy where the profit motive was to be the main cause of economic developments. According to the classical dichotomy, an increase in the total amount of money leads to a proportionate increase in all money prices, with no change in the allocation of resources or the level of real GDP, which is known as money neutrality. 


\section{Keynesian View of Public Expenditure}

Keynes categorized public expenditure as an exogenous variable that can generate economic growth instead of an endogenous phenomenon. Hereby, the belief that the role government is crucial is inevitable has it could devoid depression by increasing aggregate demand and thus, switching on the economy again by the multiplier effect.

\section{Public Choice Theory}

This theory tries to explain how public decisions are made. It involves the interactions of the voting public, the politicians, the bureaucrats and political action members. We assume that voters, politicians and bureaucrats, just like consumers, entrepreneurs and managers, act in their self-interest. For example, politicians as vote-maximizers while the electorates are welfare-maximizers. The major assumptionof this theory is that Voters, Politicians, Bureaucrats, interest groups are motivated primarily by selfinterest (Orchard \& Stretton, 1977).

Therefore, this paper shall investigate the significance of the Wagner's hypothesis to the pattern of government spending as to whether it is 'responsive' (i.e. significant to economic growth) or 'excessive' (i.e. insignificant to economic growth) in Nigeria.

\section{Empirical Review}

There exists arguments in the literature as to the relationship between the growth in public expenditure and economic growth: While some researchers argued that there exists a significant relationship between increase in the government size and growth in the economy; other researchers found that the relationship between increase in government size and economic growth is insignificant.

Maku (2009) examined the link between government spending and economic growth in Nigeria over the last three decades (1977-2006). The results of his findings showed that private and public investments have insignificant effect on economic growth during the review period.

While Appah\&Ateboh-Briggs (2013) identified the patterns of public expenditure growth in Nigeria (based on the CBN statistical bulletin) that expenditure on administration, social and community services, economic services, and transfers affects economic growth in Nigeria from the period 1961 to 2010. This work shall therefore extend these findings to 2018.

Thus, Akpan (2014) also examined Government Expenditure and Economic Growth in Nigeria but found no significant relationship between all the components of government expenditure and economic growth.

However, Okoro (2013) investigated the empirical link between government spending and economic growth in Nigeria and he reported that there exists a long run equilibrium relationship between government spending and economic growth in Nigeria.

Furthermore, (Ojong, et al 2016) examined the effect of recurrent expenditure on the growth of Nigeria economy and the link between capital expenditure and economic growth in Nigeria. They revealed from their findings that both capital and recurrent expenditure have significant and positive impact on economic growth in Nigeria.

Therefore, this study shall help in analyzing the pattern and focus of public expenditure in Nigeria, as to whether they are responsive by significant contribution to economic growth or excessive by reducing economic growth.

\section{RESEARCH METHODOLOGY}

The paper adopted Ex- post facto research design, using quantitative aggregate data of government's recurrent and capital expenditure from the Central Bank Of Nigeria (1981 -2018) to empirically validate whether the pattern of government spending (surrogated) by aggregate government expenditure on: (i) General Administration (ii) Social and Community Services (iii) Economic Services and (iv) Transfers is responsive (significant) to economic growth, which is proxied by real GDP.

The collected data sets wasanalysed in two stages. The first is the descriptive analysis using relevant tools of descriptive statistics such as mean, median, kurtosis, skewness, etc. Subsequently, the data sets were analysed based on time series regression model.

\section{MODEL SPECIFICATION}

This study posited that economic growth (GDP) depends on government expenditure into: aggregate government expenditure on: (i) General Administration (ii) Social and Community Services (iii) Economic Services and (iv) Transfers.

The multiple regression model for the analysis is given as: RGDP = $\mathrm{f}$ (Tadmin, Tsoc/comm serv., Teco serv., Ttransfer)

Where: RGDP $=$ Real Gross Domestic ProductTadmin $=$ Aggregate Expenses on General Administration

Tsoc/comm serv = Aggregate Expenses on Social \& Community services

Teco serv = Aggregate Expenses on Economic services

Ttransfer $=$ Aggregate Transfer

It should be noted that the aggregate values are the summation of both recurrent and capital expenditure components of the explanatory variables. The functional form of the relationship can therefore, be written as:

RGDP $=\alpha_{0}+\alpha_{1}$ Tadmin $_{t}+\alpha_{2}$ Tsoc/comm $_{t}$ serv. + $\alpha_{3}$ Tecoserv $_{t}+\alpha_{4}$ Ttransfer $_{t}+\varepsilon_{t}$

Where:

$\alpha_{0}=$ Intercept

$\alpha_{1}=$ Captures the effect of aggregate expenses of general administration on RGDP

$\alpha_{2}=$ Captures the effect of aggregate expenses of social \& community services on RGDP

$\alpha_{3}=$ Captures the effect of aggregate expenses on Economic services on RDGP

$\alpha_{4}=$ Captures the effect of Total Transfers on RGDP

$\varepsilon=$ Error term

$\mathrm{t}=$ Respective point in time at which data is extracted. 


\section{A priori Expectations}

\section{COEFFICIENT}

Table : Summary of A priori expectations

Aggregate Expenses on General Administration

Aggregate Expenditure on Social and Community Services

Aggregate expenditure on Economic services.

\section{EXPECTED SIGNS}

The coefficient of this independent variable is expected to have a positive relationship with economic growth. That is, $\alpha_{1}>1$. Because as the aggregate expenditure on Government's General Administration increases, the economy is expected to grow. This will lead to economic development.

The coefficient of this independent variable is expected to have a negative relationship with economic growth. That is, $\alpha_{2}<1$. Because as the aggregate expenditure on Social and Community Services are expected to reduce, when the economy is estimated to be growing.

The coefficient of this independent variable is expected to have a positive relationship with real GDP. That is, $\alpha_{3}>1$. Because as the aggregate expenditure Economic Services increase, economic growth is expected.

The coefficient of this independent variable is expected to have a negative relationship with economic growth. That is, $\alpha_{4}<1$. Because as Total Transfers increase, the GDP growth rate is negatively affected.

\section{Model Estimation and Evaluation Technique}

Appropriate estimation technique was used to obtain the numerical values of the parameters of the model depending on the ascertained time series properties. The unit root test was conducted using Philip - Perron test to establish the stationarity of all variables. Trend analysis was done to detect the general pattern of movement of the variables. Thus, the unit root were run, with all the variables at intercept and trend.

\section{RESULTS AND DISCUSSION}

DESCRIPTIVE STATISTICS

\begin{tabular}{|l|l|l|l|l|c|}
\hline & & & TECO_SERV & TSOC_COMM_SE \\
& RGDP & TADMIN_REV & & TTRANSFERS & RV \\
\hline Mean & 48926817 & 423779.3 & 161098.5 & 554333.9 & 445485.0 \\
\hline Median & 23068845 & 163776.1 & 70987.93 & 223593.3 & 211446.5 \\
\hline Maximum & $1.40 \mathrm{E}+08$ & 1619333. & 689900.0 & 2913803. & 1837222. \\
\hline Minimum & 13779255 & 917.2980 & 448.7967 & 3863.202 & 1010.693 \\
\hline Std. Dev. & 46039080 & 519779.7 & 199942.8 & 727181.1 & 520281.0 \\
\hline Skewness & 1.157601 & 0.896116 & 1.040925 & 1.651235 & 0.997217 \\
\hline Kurtosis & 2.557803 & 2.263201 & 2.807587 & 5.077725 & 2.794358 \\
\hline & & & & & 6.365093 \\
\hline Jarque-Bera & 8.796520 & 5.945361 & 6.920944 & 24.10347 & 0.041480 \\
\hline Probability & 0.012299 & 0.051166 & 0.031415 & 0.000006 & 16928431 \\
\hline & & & & & 21064690 \\
\hline Sum & $1.86 \mathrm{E}+09$ & 16103612 & 6121742. & $1.96 \mathrm{E}+13$ & $1.00 \mathrm{E}+13$ \\
\hline Sum Sq. Dev. & $7.84 \mathrm{E}+16$ & $1.00 \mathrm{E}+13$ & $1.48 \mathrm{E}+12$ & & 38 \\
\hline
\end{tabular}

Similarly, total Admin expenditure (TADMIN_REV) has a

From the above table, RGDP has a mean value of 48926817 , median of 23068845 , maximum and minimum of $1.40 \mathrm{E}+08$ and 13779255 respectively. With a standard deviation of 46039080, the skewness is 1.157601, indicating positive skewness and right long-tailed. The Kurtosis of 2.557803 is less than 3 , indicating a case of platykurtic, meaning that more values of the data are below the mean. The Jacque- Bera statistic of 8.796520 and probability value of 0.012299 reveals a normal distribution. mean value of 423779.3, median of 163776.1, maximum and minimum of 1619333 and 917.2980 respectively. With a standard deviation of 519779.9, the skewness is 0.896 with kurtosis of 2.26, which is less than 3, thereby indicating a case of platykurtic distribution, meaning that more of the data values are below the mean. The Jargue - Bera statistic of 5.95 with probability of 0.05 reveals a normal distribution.

Furthermore, total expenditure on economic services (TECO_SERV) has a mean of 161098.5, median of 70987.93 
while the mean of 161098.5 , median of 70987.93 while the maximum and minimum values of 689900.0 and 448.7967 respectively. The Standard deviation of 199942.8 with a skewness of 1.04, indicates a positive skewness that is right -tailed. Also, the Jargue - bera statistic of 6.92 with probability value of 0.03 , still follows a normal distribution. With a standard deviation of 46039080 , the skewness is 1.157601 , indicating positive skewness and right long-tailed. The Kurtosis of 2.557803 is less than 3, indicating a case of platykurtic, meaning that more values of the data are below the mean. The Jacque- Bera statistic of 8.796520 and probability value of 0.012299 reveals a normal distribution.

Total transfers (Ttransfers) has a mean value of 554,333. 9 , median of 223593.3, maximum of 2913803 and minimum of
3863.202, standard deviation of 727181.6; skewness of 1.65 and kurtosis of 5.07, which is more than 3 , thereby, indicating a case of lepokurtic, showing that its distribution is highly peaked. This is a strong indication of the reason for the increase in government expenditure in Nigeria.

Aggregate expenditure on social and community service (TSOC_COM_SERV) has a mean of 445485, median of 211446.5 while its minimum and maximum values are 1837222 and 1010.693. Its Standard deviation is 520281 while the Kurtosis is 2.794358 , which is less than 3, showing the case of Platykurtuc distribution of the data, below the mean. The Jacque-Bera statistic of 6.365 with probability value of 0.04 , also reveals a normal distribution.

Correlation Analysis

\begin{tabular}{|c|c|c|c|c|c|}
\hline & RGDP & TADMIN_REV & TECO_SERV_ & $\begin{array}{l}\text { TSOC_COMM_SE } \\
\text { RV }\end{array}$ & TTRANSFERS \\
\hline RGDP & 1 & $\begin{array}{l}0.9616594389955 \\
134\end{array}$ & $\begin{array}{l}0.8634240648059 \\
781\end{array}$ & $3^{0.946622729611535}$ & $\begin{array}{l}0.9202262052327 \\
106\end{array}$ \\
\hline TADMIN_REV & $\begin{array}{l}0.9616594389955 \\
134\end{array}$ & 1 & $\begin{array}{l}0.9398447886369 \\
656\end{array}$ & $88^{0.978918566919508}$ & $\begin{array}{l}0.9271040029000 \\
281\end{array}$ \\
\hline TECO_SERV_ & $\begin{array}{l}0.8634240648059 \\
781\end{array}$ & $\begin{array}{l}0.9398447886369 \\
656\end{array}$ & 1 & $9^{0.930863622038937}$ & $7 \int_{89}^{0.7984777855613}$ \\
\hline $\begin{array}{l}\text { TSOC_COMM_SE } \\
\text { RV }\end{array}$ & $\begin{array}{l}0.9466227296115 \\
353\end{array}$ & $\begin{array}{l}0.9789185669195 \\
088\end{array}$ & $\begin{array}{l}0.9308636220389 \\
379\end{array}$ & 1 & $\begin{array}{l}0.9309454419732 \\
539\end{array}$ \\
\hline TTRANSFERS & $\begin{array}{l}0.9202262052327 \\
106\end{array}$ & $\begin{array}{l}0.9271040029000 \\
281\end{array}$ & 89 & $9^{0.930945441973253}$ & 1 \\
\hline
\end{tabular}

The correlation matrix table as shown above. TADMIN_REV has a highly strong association with RGDP as reflected by the coefficient figure of 0.962. Similarly, the correlation between TECO_SERV and RGDP is 0.86, which

is equally strong. TSOC_COMM SERV and RGDP has a correlation coefficient of 0.95 . Likewise, TTRANSFERS and RGDP has a coefficient of correlation of 0.92 which also is a very strong relationship.

Phillip-Perron Unit Root Test

\begin{tabular}{|l|c|c|c|c|}
\hline Variable & $\begin{array}{c}\text { Phillip } \\
\text { Statistic }\end{array}$ & $5 \%$ critical value & Probability & $\begin{array}{c}\text { Order } \\
\text { integration }\end{array}$ \\
\hline RGDP & -5.583073 & -3.540328 & 0.0003 & $\mathrm{I}(1)$ \\
\hline TADMIN_REV & -5.280480 & -3.540328 & 0.0007 & $\mathrm{I}(1)$ \\
\hline TECO_SERV & -7.938615 & -3.540328 & 0.0000 & $\mathrm{I}(1)$ \\
\hline TSOC_COM & -6.280007 & -3.540328 & 0.0000 & $\mathrm{I}(1)$ \\
\hline Ttransfers & -5.855185 & -3.540328 & 0.0001 & $\mathrm{I}(1)$ \\
\hline
\end{tabular}

Because, the explanatory variables are integrated at order proceed to estimate our model using Error Correction Model (ECM)

1 , that is $\mathrm{I}(1)$. Based on this outcome of the Unit root test, we

\begin{tabular}{|c|c|c|c|c|}
\hline \multicolumn{5}{|c|}{ Dependent Variable: D(RGDP) } \\
\hline \multicolumn{5}{|l|}{ Method: Least Squares } \\
\hline \multicolumn{5}{|l|}{ Date: 03/04/20 Time: $16: 38$} \\
\hline \multicolumn{5}{|l|}{ Sample (adjusted): 19822018} \\
\hline \multicolumn{5}{|c|}{ Included observations: 37 after adjustments } \\
\hline Variable & Coefficient & Std. Error & t-Statistic & Prob. \\
\hline $\mathrm{C}$ & 1459015. & 1503299. & 0.970542 & 0.3393 \\
\hline D(TADMIN_REV) & 65.24925 & 17.45863 & 3.737363 & 0.0008 \\
\hline D(TECO_SERV_) & 8.845235 & 22.02490 & 0.401602 & 0.6907 \\
\hline D(TSOC_COMM_SERV) & -17.29411 & 11.83005 & -1.461879 & 0.1538 \\
\hline D(TTRANSFERS) & -1.908956 & 9.324501 & -0.204725 & 0.8391 \\
\hline $\operatorname{ECM}(-1)$ & -0.198554 & 0.140903 & -1.409155 & 0.1687 \\
\hline
\end{tabular}




\begin{tabular}{|l|l|l|l|}
\hline & & \multicolumn{1}{|c|}{} & 3360591. \\
\hline R-squared & 0.461909 & Mean dependent var & 9701094. \\
\hline Adjusted R-squared & 0.375120 & S.D. dependent var & 34.69057 \\
\hline S.E. of regression & 7668653. & Akaike info criterion & 34.95180 \\
\hline Sum squared resid & $1.82 \mathrm{E}+15$ & Schwarz criterion & 34.78267 \\
\hline Log likelihood & -635.7756 & Hannan-Quinn criter. & 1.322782 \\
\hline F-statistic & 5.322208 & Durbin-Watson stat & \\
\hline Prob(F-statistic) & 0.001209 & & \\
\hline
\end{tabular}

From the ECM results obtained above, Aggregate Expenditure on Administration (TADMIN_REV) has a coefficient of 65.24925 , with a standard error of 17.45 , which is less than half of the coefficient, indicating that the variable is a statistically significant determinant of the variation of the real GDP (RGDP). This is equally confirmed by the probability value of 0.0008 . The ECM (-1) implies that the adjustment rate to long run relationship is approximately $20 \%$ (i.e. 19.85). While the probability values of the other explanatory variables, which include: Aggregate Expenditure on: Economic Services (TECO_SERV); Social and Community Services (SOC_COMM_SERV) and Transfers (Ttransfers) are more than 0.05, signifying that they are not individually statistically significant, meanwhile, when all these variable are jointly paired, they all exhibit a joint statistical signifance. The $\mathrm{R}$ square shows that $46.2 \%$ variation in RGDP are caused by Economic Services, Social and Community Services ,transfers and administration while the remaining $53.8 \%$ variations are caused by other variables not captured in the study.

Post Estimation Test

\begin{tabular}{|l|l|l|l|}
\hline Test & Statistics & Value & Probability \\
\hline NORMALITY & Jarque-Bera & 68.42999 & 0.000 \\
\hline HETEROSCEDATICY & F-STASTICS & 8.083690 & 0.1058 \\
\hline AUTOCORRELATION & F-STATISCS & 8.285122 & 0.1234 \\
\hline
\end{tabular}

Source: Author's computation

The Jarque-Bera statistics and probability values of the estimated models, stood at 68.42999 and 0.000 respectively, which revealed that the error term is not normally distributed. In addition, B-G serial correlation LM test result revealed f-statistics and probability values of 8.285122 and 0.1234 respectively, which

\section{SERIAL CORRELATION}

Breusch-Godfrey Serial Correlation LM Test:

\begin{tabular}{llll}
\hline \hline F-statistic & 8.285122 & Prob. F(2,29) & 0.1234 \\
Obs*R-squared & 10.440164 & Prob. Chi-Square(2) & 0.2147 \\
\hline \hline
\end{tabular}

established that there is no serial correlation between successive error terms. Finally, the F-statistics and probability values for heteroscedastic test is 8.083690 and 0.1058 respectively, which ascertain that the error term has constant variance i.e. homoscedastic

\section{HETEROSKEDASCTICITY}

Heteroskedasticity Test: Breusch-Pagan-Godfrey

\begin{tabular}{llll}
\hline \hline F-statistic & 8.083690 & Prob. F(5,31) & 0.1058 \\
Obs*R-squared & 14.69283 & Prob. Chi-Square(5) & 0.0118 \\
Scaled explained SS & 37.52619 & Prob. Chi-Square(5) & 0.0000 \\
\hline \hline
\end{tabular}

\section{SUMMARY, CONCLUSION \& RECOMMENDATION}

\section{Summary}

The purpose of this study is to empirically investigate whether the pattern of government spending in Nigeria is responsive (that is, significant to economic growth) or excessive (that not significant to economic growth), thereby testing whether the Wagner's theory of increasing State Activity is valid in Nigeria or not.

Based on the Wagner's law, which states that "as the economy progresses over time, the activities and roles of the government increase". Thus, Wagner posited that growth in government expenditure, is a function of growth in GDP. According to his position, there should be significant relationship between economic growth and growth in public expenditure. Thus, the pattern of government spending ought to be responsive to economic growth and the demands and aspiration of the citizens. 
From this study therefore, we can conclude from the descriptive statistics that the kurtosis showed that government spending in Nigeria tends to be excessive, as aggregate expenditure on transfers (Ttransfers) is leptokurtic, meaning that government spending by transfers is likely skewed. This may account for the reason why there exists so many leakages in the economy, that is, areas through which funds are diverted for other selfish interests, without maximising economic welfare. Furthermore, based on the ECM model, only aggregate expenditure on Administration ((TADMIN_REV) is statistically significant to RGDP. Rather, the approri expectation was that aggregate expenditure on Economic services (TECO_SERV) and Social and Community services (SOC_COMM_SERV) are expected to be positively skewed to show government priority areas of public expenditure.

\section{Conclusion}

Based on the findings of this study, it could be established that when all the aggregates expenditure proxies are related individually, they will not exert any significance, while when they are jointly related, they are established to be significance. This hereby shows that the pattern of government expenditure responses effectively to the Nigeria economic growth under the study year.

\section{Recommendation}

Based on the research findings, this study suggests the need for a reversal in declining budgetary allocation to the educational and health sector in order to provide the sectors with the needed revenue which is necessary in influencing aggregate output of the economy.

Hence, there is the need to re-direct the excessive expenditures of government on its officials in both the house of senate and house of representative to these pivotal sectors that is capable of stimulating economic growth of the Nigerian economy.

\section{REFERENCES}

[1] Adeolu, A. M., \&Osabuohien, E. (2007). Analysis of the cost of governance and options for its reduction in Nigeria.

[2] Akonji, D. R., Olateju, A. O., \& Abba, M. W. (2013). Nexus between public expenditure and economic growth by testing Wagner's law time series: Evidence from Nigeria. International Journal of Development and Sustainability, 2(4), 2383-2395.

[3] Alley, I., Asekomeh, A., Mobolaji, H., \& Adeniran, Y. A. (2014). Oil price shocks and Nigerian economic growth. European Scientific Journal, ESJ, 10(19).

[4] Amassoma, D., Nwosa, P., \&Ajisafe, R. (2011). Components of government spending and

[5] economic growth in Nigeria: An error correction modelling. Journal of Economics and Sustainable Development, IISTE (2),(4), 17-19.

[6] Anyanwu, J. C. (1997). Poverty in Nigeria: Concepts, measurement and determinants. Poverty alleviation in Nigeria, 93-120.

[7] Appah, E., \&Ateboh-Briggs, P. B. (2013). Cointegration of public sector expenditure patterns and growth of Nigeria. Developing Country Studies, 3(9), 174-188.

[8] Essays, UK. (November 2013). Review of Theories on Government Expenditure Economics

[9] Essay. Retrieved from https://www.ukessays.com/essays/economics/review-of-theories-on-go vernment-expenditure-economics-essay.php?

[10] Ezirim, B. C., \&Ofurum, C. O. (2003). Public expenditure growth and inflation in developed and less developed countries. Nigerian Business and Social Review, 2(1), 75-94.

[11] Ganiyu, L. O., Olawale, A. N., Ajibade, I. S., \&Abisola, I. R. (2016). The Nexus between

[12] Nigerian Government Spending and Domestic Output in the Presence of Long-Term Crude Oil Price Shock: A Conditional Unrestricted
Equilibrium Correction Model Approach. Open Journal of Statistics, 6(03), 412.

[13] Gbenga, A., Babatunde, O. O., \& Esther, L. (2015). The Effect of Sectoral PublicInvestment Expenditure On Private Investment In Nigeria: An Error-correction Analysis. European Journal of Business and Social Sciences, 4(04), 87-104.

[14] Ighodaro, C. A., \&Oriakhi, D. E. (2010). Does the Relationship Between Government Expenditure and Economic Growth Follow Wagner $^{\text {ee }} \mathrm{s}$ Law in Nigeria.Annals of University of Petrosani Economics, 10(2), 185-198.

[15] Jibir, A., \&Aluthge, C. (2019). Modelling the determinants of government expenditure in Nigeria. Cogent Economics \& Finance, $7(1), 1620154$.

[16] Maku, O. E. (2009). Does government spending spur economic growth in Nigeria?

[17] Modebe, N. J., Okafor, R. G., Onwumere, J. U. J., \&Ibe, I. G. (2012). Impact of recurrent and capital expenditure on Nigeria's economic growth. European Journal of Business and Management, 4(19), 66-74.

[18] Ojong, C. M., Nkamare, S. O., \& Anthony, O. (2016). Government expenditure and its implications on Nigerian economy. IOSR Journal of Humanities and Social Science, 21(1), 50-55.

[19] Okafor, C. A., \&Eiya, O. (2011). Determinants of growth in government expenditure: An

[20] empirical analysis of Nigeria. Research journal of business management, 5(1), 44-50.

[21] Okoro, A. S. (2013). Government spending and economic growth in Nigeria (1980-2011). Global Journal of Management and Business Research

[22] Onyinyechi, O. C., \& Okafor, M. C. (2016). Efficiency and Accountability of Public Sector

[23] Revenue and Expenditure in Nigeria (1970-2014). European Journal of Accounting, Auditing and Finance Research, 4(7), 23-42.

[24] Taiwo, I. O. (1989). Determinants of federal government expenditure in Nigeria. Social and economic studies, 205-222.

[25] Theophilus, A. A., \&Perpectua, E. C. (2016). Budget Padding: The Nigerian Perspective.

[26] International Journal of Advanced Academic Research $\mid$ Social \& Management Sciences, 2, 12.

[27] Temitope Lydia A. Leshoro (2017). Investigating the non-linear Wagner's hypothesis in South Africa, African Journal of Economic and Management Studies, 8, 4, (462).

[28] Ukwueze, E. R. (2015). Determinants of the Size of Public Expenditure in Nigeria. SAGE Open, 5(4), 2158244015621346. 